\title{
Vietnamese High School Students' Perceptions of Academic Advising
}

\author{
Son Van Huynh and Vinh-Long Tran-Chi ${ }^{1}$ \\ Educational Psychology Research Group \\ Ho Chi Minh City University of Education \\ Ho Chi Minh City, Vietnam
}

\begin{abstract}
The purpose of this study is to examine the relationship between the current existing obstacle and Vietnamese high school students' need for academic advising. A group of 1,200 children (449 boys and 751 girls from grade 6 through 12) from seven high schools participated in the survey. They completed a 24-item questionnaire about their study obstacle and academic advising need. The results showed a significant positive correlation between high school students' current existing obstacles and their need for academic advising. Moreover, the average point of high school students' current existing study obstacles was 2.67 and the need for academic advising was 3.18. The results suggested high school students facing obstacles in their study have the need to be consulted on these difficulties. Different school levels and living conditions result in different current obstacles and needs of academic advising during their study.
\end{abstract}

Keywords: Academic Advising; High School Student; Study Obstacle.

\section{Introduction}

In Vietnam, more than 200,000 high school students quit school every year (Thanh Nien, 2011). According to statistics from the Ministry of Education and Training, the school dropout rate at the primary level is 0.16 percent; at junior high school 1.37 percent; and at senior high school 1.79 percent (An, 2015). For instance, in Ho Chi Minh City more than 5400 high school students were dropped out (Pham, 2016); in Hanoi capital more than 1,500 high school students were dropped out (Phan \& Khanh, 2012); and in An Giang province nearly 5000 high school students were dropped out (Duc, 2013). According to some Vietnamese educational experts, one of the contributing factors or students' failures came from poor academic advising system (Nguyen et al., 2013).

Academic advising is one content in the school counseling program. Academic advising has been in existence for quite a long time in many parts of the world. 
Historically, the earlier version of academic advising focuses merely on academic aspects of student' s life. However, with the change of students demographic, the focus of academic advising experiences gradual change. A present, academic advising is seen as a continuing process in which students are assisted in personal development and achievement of educational and career goals. The provision of advisory services performs by the academic advisors is changed into guidance and development to produce a well-rounded workforce (Nguyen et al., 2013). School counseling program for students, in the 1950s, is comprised of three main domains: career orientation, academic advising, individual/society (Sculli, 2011). Study obstacle is a serious problem because of the negative impacts on students' performance. Students have the need of academic advising when facing study obstacles in order to overcome these problems (Sculli, 2011). Recent researches show that those students, after being consulted, become more self-respected, motivated and active in participating in class activities with more efforts in performing tasks more effectively (Legum \& Hoare, 2004), know how to communicate better as well as become more confident and self-esteem (Flitton \& Buckroyd, 2005); therefore, they achieve better study results compared to those who have not been consulted (Branham, 2009). Sink and Stroh (2003) discovers that those students with Comprehensive School Counseling Programs (CSCP) have higher scores and perform better (Lapan, Gysbers, \& Petroski, 2001; Sink, Akos, Turnbull, \& Mvududu, 2008), write reports better and feel well-prepared for future (Lapan, Gysbers, \& Sun, 1997) compared to those students in a normal class. Moreover, counseling efficiency is related to students' positive future prospect (Dellana \& Snyder, 2004).

According to (Sculli, 2011) on high-school students' need for a career, individual/society, and academic advising. Academic advising needs to be identified by students included study skill support, exam anxiety support, and help with motivation. Career advising needs were to identify by students included wanting more information about careers and more guidance with career decision-making. Lastly, individual/society advising needs identifying by students included wanting to counsel for domestic problems dealing with family and peer relations and puberty problems. High-school students have the highest need for academic advising but the lower need for individual/society. Regarding the need for academic advising, there is one difference between gender and school levels. Branham (2009) examined the effect of counselor "signaling" on students, which is the process of providing information to students about college. The researcher found that that the students who were not receiving as much "signaling" had less rigorous college preparatory course loads, knew less about scholarships and tuition, and maintained less knowledge about what was necessary to achieve continued success beyond high school. It means those students receiving more counseling information, related to university orientation program; achieve better results than those who do not receive such information. Legum and Hoare (2004) conduct research on career impacts on potentially risky students. The experimental group's career awareness doubles that of the control group's. Those students, after a career orientation program, witness an increase in their self-esteem, higher motivation, 
more frequent class participation and more efforts in achieving better outcomes. Dellana and Snyder (2004) perform another research on the impacts of race, gender, school level, study outcomes and consultancy efficiency on high-school students' future potentiality. Their research discovers that academic advising efficiency is closely connected to students' positive future potentiality. Flitton and Buckroyd (2005) research to evaluate school counseling program upon students during schooling period on English children with complicated needs. A case study discovers changes in communication, consciousness, and confidence in one student. Gerrity and DeLucia-Waack (2007) survey the effectiveness of group advising.

Although academic advising is not a new topic, there are still a limited number of studies done in Vietnam, especially for Vietnamese high school students. To fill this gap, this research is conducted to empirically explore high school students' perception of academic advising in Can Tho city, Vietnam. The aim of this research is to examine the relationship between the current existing obstacle and Vietnamese high school students' need for academic advising. In view of the basic aim of the research, the following problem has been set:

- Is there a statistically significant relationship between the current existing obstacle and Vietnamese high school students' need for academic advising?

In accordance with the aim and the problem of the research, the following null hypothesis was tested:

- There is no significant difference between the current existing obstacle and Vietnamese high school students' need for academic advising.

The research starts with reviewing the empirical literature of students' perception of academic advising. A research methodology is introduced in the second section, followed by results and discussion. The last section is the conclusion.

\section{Methods and Materials}

In this study, a questionnaire was chosen as a design tool to collect information from an individual. This kind of questionnaire needs the participant to respond by selecting the answer options that have been provided. The questionnaires were distributed in hardcopy format to high school students.

\subsection{Participants}

The convenience sampling method was used to recruit students who volunteered to help with the study and administer the survey. The survey instrument was distributed to 1300 Vietnamese students of seven high schools located in Can Tho city, Vietnam, of which 1200 surveys were returned, for a $92.30 \%$ return rate, which exceeds the $30 \%$ response rate most researchers require for analysis (Dillman, 2000). The sample of this study was drawn from 1200 respondents who completed the survey instrument. There were more girls $(62.6 \%)$ than boys (37.4\%) among the 1200 Vietnamese high school students who were surveyed. Of these, 726 (60.5\%) were junior high school students, and 474 
$(39.5 \%)$ were senior high school students. 68 of these students were in grade 6 , seven were in grade 7,325 were in grade 8,324 were in grade 9, 69 were in grade 10, 246 were in grade 11 and 159 were grade 12 students. Table 1 shows the distribution of participants.

Table 1: An overview of survey participants

\begin{tabular}{|c|c|c|c|}
\hline \multirow{3}{*}{ Gender } & & $\mathbf{n}$ & $\%$ \\
\hline & Boy & 449 & 37.4 \\
\hline & Girl & 751 & 62.6 \\
\hline \multirow{6}{*}{ Year of birth } & 2001 & 247 & 20.6 \\
\hline & 2002 & 446 & 37.2 \\
\hline & 2003 & 109 & 9.1 \\
\hline & 2004 & 227 & 18.9 \\
\hline & 2005 & 153 & 12.8 \\
\hline & 2006 & 18 & 1.5 \\
\hline \multirow{7}{*}{ School } & An Hòa Junior high school & 117 & 9.8 \\
\hline & Trà An Junior high school & 168 & 9.8 \\
\hline & An Thới Junior high school & 51 & 4.3 \\
\hline & Bình Thủy Junior high school & 132 & 11.0 \\
\hline & $\begin{array}{l}\text { Nguyễn Việt Hồng } \\
\text { Senior high school }\end{array}$ & 156 & 13.0 \\
\hline & $\begin{array}{c}\text { Lý Tự Trọng } \\
\text { Senior high school }\end{array}$ & 90 & 7.5 \\
\hline & $\begin{array}{c}\text { Bùi Hữu Nghĩa } \\
\text { Senior high school }\end{array}$ & 96 & 8.0 \\
\hline \multirow[t]{2}{*}{ Grade } & Junior & 726 & 60.5 \\
\hline & Senior & 474 & 39.5 \\
\hline \multirow{7}{*}{ Class } & Class 6 & 68 & 5.7 \\
\hline & Class 7 & 9 & 0.8 \\
\hline & Class 8 & 325 & 27.1 \\
\hline & Class 9 & 324 & 27.0 \\
\hline & Class 10 & 69 & 5.8 \\
\hline & Class 11 & 246 & 20.5 \\
\hline & Class 12 & 159 & 13.3 \\
\hline
\end{tabular}

\subsection{Measure}

Questionnaires are designed to survey on high school students from grade 6 through grade 12 in Can Tho city, Vietnam. This research starts in January 2019 and finishes in April 2019. First, social-demographic items were introduced in the questionnaire. Then, Vietnamese high school students' perceptions of academic advising of participants were measured by a total of 24 items. Specifically, study obstacle was assessed by 12 items and academic advising by 12 items. The responses of the participants were provided in 5 different levels based on a 5-point Likert scale (Croasmun \& Ostrom, 2011).

\subsection{Analyses}

All participants were provided informed consent to participate in the study after receiving an explanation of the purpose of the research. The research was approved by the ethics committee of the Ho Chi Minh City University of 
Education, Ho Chi Minh City, Vietnam. The Statistical Package for the Social Sciences (SPSS) version 16 was used for data analyses. The coding procedure was performed as follow: 1 = Strongly disagree, 2 = Disagree, $3=$ Neutral, $4=$ Agree, 5 = Strongly agree. For the purpose of transforming the discrete values into ranks, distance value was calculated as:

$$
\text { (Maximum }- \text { Minimum) } / \mathrm{n}=(5-1) / 5=0.8
$$

(Jaafar, Arifin, Aiyub, Razman, \& Kamaruddin, 2017)

Therefore, the meanings of the rankings are judged as below:

$$
\begin{aligned}
& +1.00-1.80=\text { Totally unnecessary } \\
& +1.81-2.60=\text { Unnecessary } \\
& +2.61-3.40=\text { Average/Optional (Necessity is optional) } \\
& +3.41-4.20=\text { Rather problematic/Necessary } \\
& +4.21-5.00=\text { Very problematic/Totally necessary }
\end{aligned}
$$

First, descriptive statistics were calculated as a preliminary analysis. Second, a Pearson correlation was conducted to evaluate correlations between the current existing obstacle and Vietnamese high school students' need for academic advising. Results are reported at a statistical threshold of $p<0.05$

\section{Results}

The participants scored in the average range on the questionnaire. The mean

\begin{tabular}{|c|c|c|c|c|c|c|c|c|c|}
\hline & \multicolumn{5}{|c|}{ Level } & \multirow[t]{2}{*}{$\mathbf{M}$} & \multirow[t]{2}{*}{ SD } & \multirow[t]{2}{*}{ Order } \\
\hline & & 1 & 2 & 3 & 4 & 5 & & & \\
\hline \multirow{2}{*}{$\begin{array}{l}\text { Study target/motivation } \\
\text { identification }\end{array}$} & $\mathrm{n}$ & 301 & 254 & 415 & 147 & 83 & \multirow{2}{*}{2.55} & \multirow[b]{2}{*}{1.18} & \multirow{2}{*}{9} \\
\hline & $\%$ & 25.1 & 21.2 & 34.6 & 12,3 & 6.9 & & & \\
\hline \multirow{2}{*}{$\begin{array}{l}\text { Compulsory study content } \\
\text { identification }\end{array}$} & $\mathrm{n}$ & 207 & 270 & 521 & 138 & 64 & \multirow{2}{*}{2.65} & \multirow{2}{*}{1.06} & \multirow{2}{*}{6} \\
\hline & $\%$ & 17.3 & 22.5 & 43.4 & 11.5 & 5.3 & & & \\
\hline \multirow{2}{*}{$\begin{array}{l}\text { Appropriate study } \\
\text { method identification }\end{array}$} & $\mathrm{n}$ & 167 & 257 & 473 & 201 & 102 & \multirow{2}{*}{2.85} & \multirow{2}{*}{1.12} & \multirow{2}{*}{2} \\
\hline & $\%$ & 13.9 & 21.4 & 39.4 & 16.8 & 8.5 & & & \\
\hline \multirow{2}{*}{$\begin{array}{l}\text { Logical time management } \\
\text { for study }\end{array}$} & $\mathrm{n}$ & 212 & 215 & 416 & 260 & 97 & \multirow{2}{*}{2.85} & \multirow{2}{*}{1.18} & \multirow{2}{*}{2} \\
\hline & $\%$ & 17.7 & 17.9 & 34.7 & 21.7 & \begin{tabular}{|l|}
8.1 \\
\end{tabular} & & & \\
\hline \multirow{2}{*}{$\begin{array}{l}\text { Search for further study } \\
\text { material }\end{array}$} & $\mathrm{n}$ & 203 & 311 & 416 & $\begin{array}{l}197 \\
\end{array}$ & \begin{tabular}{|l|}
73 \\
\end{tabular} & \multirow{2}{*}{2.69} & \multirow{2}{*}{1.11} & \multirow{2}{*}{4} \\
\hline & $\%$ & 16.9 & 25.9 & 34.7 & 16.4 & \begin{tabular}{|l|}
6.1 \\
\end{tabular} & & & \\
\hline \multirow{2}{*}{$\begin{array}{l}\text { Information management } \\
\text { in the study }\end{array}$} & $\mathrm{n}$ & 219 & 244 & 523 & 152 & 62 & \multirow{2}{*}{2.66} & \multirow{2}{*}{1.07} & \multirow{2}{*}{5} \\
\hline & $\%$ & 18.3 & 20.3 & 43.6 & 12.7 & 5.2 & & & \\
\hline \multirow{2}{*}{$\begin{array}{l}\text { Note-taking of study } \\
\text { content }\end{array}$} & $\mathrm{n}$ & 316 & 307 & 420 & 122 & 35 & \multirow{2}{*}{2.38} & \multirow{2}{*}{1.06} & \multirow{2}{*}{11} \\
\hline & $\%$ & 26.3 & 25.6 & 35.0 & 10.2 & 2.9 & & & \\
\hline \multirow{2}{*}{ Observation during study } & $\mathrm{n}$ & 312 & 213 & 523 & 94 & 58 & \multirow{2}{*}{2.48} & & 10 \\
\hline & $\%$ & 26.0 & 17.8 & 43.6 & 7.8 & 4.8 & & 1.10 & 10 \\
\hline Listening and & $\mathrm{n}$ & 249 & 201 & 546 & 139 & 65 & & & \\
\hline $\begin{array}{l}\text { understanding study } \\
\text { content }\end{array}$ & $\%$ & 20.8 & 16.8 & 45.5 & 11.6 & 5.4 & 2.64 & 1.09 & 7 \\
\hline
\end{tabular}
score for the sample on the study obstacles that high school students face was 2.67 (SD = 0.85). The mean score for the students' perceptions of academic advising was $3.18(\mathrm{SD}=0.98)$. Mean, standard deviation and percentage values about these variables are shown in Table 2 and 3.

Table 2: Students' study obstacles 


\begin{tabular}{|c|c|c|c|c|c|c|c|c|c|}
\hline \multirow{2}{*}{$\begin{array}{l}\text { Cooperation in study } \\
\text { group work }\end{array}$} & $\mathrm{n}$ & 264 & 246 & 462 & 176 & 52 & \multirow{2}{*}{2.59} & \multirow{2}{*}{1.12} & \multirow{2}{*}{8} \\
\hline & $\%$ & 22.0 & 20.5 & 38.5 & 14.7 & \begin{tabular}{|l|}
4.3 \\
\end{tabular} & & & \\
\hline \multirow{2}{*}{$\begin{array}{l}\text { Idea presentation to } \\
\text { teachers and classmates }\end{array}$} & $\mathrm{n}$ & 207 & 244 & 441 & 209 & 99 & \multirow{2}{*}{2.79} & \multirow{2}{*}{1.16} & \multirow{2}{*}{3} \\
\hline & $\%$ & 17.3 & 20.3 & 36.8 & 17.4 & 8.3 & & & \\
\hline \multirow{2}{*}{$\begin{array}{l}\text { Application of } \\
\text { accumulated knowledge } \\
\text { into reality }\end{array}$} & $\mathrm{n}$ & 218 & 240 & 368 & 232 & 142 & \multirow[b]{2}{*}{2.87} & \multirow[b]{2}{*}{1.25} & \multirow[b]{2}{*}{1} \\
\hline & $\%$ & 18.2 & 20.0 & 30.7 & 19.3 & 11.8 & & & \\
\hline \multicolumn{7}{|l|}{\begin{tabular}{|l|} 
Total \\
\end{tabular}} & 2.67 & 0.85 & \\
\hline
\end{tabular}

Among the 12 items of students' study obstacles, the top five indicators, listed from the highest to the lowest average points, are as below: Application of accumulated knowledge into reality (2.87), Appropriate study method selection as well as Logical study time management (2.85), Idea presenting to teachers and classmates (2.79), Searching for further study material (2.69), Information management in study (2.66). The five indicators with the lowest average point are as below: Taking note of study content (2.38), Observation in the study (2.48), Study target identification (2.55), Cooperation in study group work (2.59), Listening and understanding study content (2.64).

Table 3: Students' need of academic advising

\begin{tabular}{|c|c|c|c|c|c|c|c|c|c|}
\hline & \multicolumn{5}{|c|}{ Level } & \multirow{2}{*}{$\mathbf{M}$} & \multirow{2}{*}{ SD } & \multirow{2}{*}{ Order } \\
\hline & & 1 & 2 & 3 & 4 & 5 & & & \\
\hline \multirow{2}{*}{$\begin{array}{l}\text { Study target/motivation } \\
\text { identification }\end{array}$} & $\mathrm{n}$ & 177 & 111 & 365 & 365 & 182 & \multirow{2}{*}{3.22} & \multirow{2}{*}{1.24} & \multirow{2}{*}{6} \\
\hline & $\%$ & 14.8 & 9.3 & 30.4 & 30.4 & 15.2 & & & \\
\hline \multirow{2}{*}{$\begin{array}{l}\text { Compulsory study content } \\
\text { identification }\end{array}$} & $\mathrm{n}$ & 164 & 126 & 333 & 427 & 150 & \multirow{2}{*}{3.23} & \multirow{2}{*}{1.20} & \multirow{2}{*}{5} \\
\hline & $\%$ & 13.7 & 10.5 & 27.8 & 35.6 & 12.5 & & & \\
\hline \multirow{2}{*}{$\begin{array}{l}\text { Appropriate study method } \\
\text { identification }\end{array}$} & $\mathrm{n}$ & 147 & 106 & 356 & 338 & 253 & \multirow{2}{*}{3.37} & \multirow{2}{*}{1.25} & \multirow{2}{*}{2} \\
\hline & $\%$ & 12.3 & 8.8 & 29.7 & 28.2 & 21.1 & & & \\
\hline \multirow{2}{*}{$\begin{array}{l}\text { Logical time management } \\
\text { for study }\end{array}$} & $\mathrm{n}$ & 145 & 201 & 270 & 340 & 244 & \multirow{2}{*}{3.28} & \multirow{2}{*}{1.29} & \multirow{2}{*}{3} \\
\hline & $\%$ & 12.1 & 16.8 & 22.5 & 28.3 & 20.3 & & & \\
\hline \multirow{2}{*}{$\begin{array}{l}\text { Search for further study } \\
\text { material }\end{array}$} & $\mathrm{n}$ & 150 & 154 & 398 & 329 & 169 & \multirow{2}{*}{3.18} & \multirow{2}{*}{1.19} & \multirow{2}{*}{8} \\
\hline & $\%$ & 12.5 & 12.8 & 33.2 & 27.4 & 14.1 & & & \\
\hline \multirow{2}{*}{$\begin{array}{l}\text { Information management } \\
\text { in the study }\end{array}$} & $\mathrm{n}$ & 133 & 204 & 366 & 387 & 110 & \multirow{2}{*}{3.11} & \multirow{2}{*}{1.13} & \multirow{2}{*}{9} \\
\hline & $\%$ & 11.1 & 17.0 & 30.5 & 32.3 & 9.2 & & & \\
\hline \multirow{2}{*}{$\begin{array}{l}\text { Note-taking of study } \\
\text { content }\end{array}$} & $\mathrm{n}$ & 190 & 208 & 389 & 316 & 97 & \multirow{2}{*}{2.94} & & \\
\hline & $\%$ & 15.8 & 17.3 & 32.4 & 26.3 & 8.1 & & 1.17 & 12 \\
\hline Observation during study & $\mathrm{n}$ & 191 & 212 & 357 & 334 & 106 & 206 & 120 & 11 \\
\hline & $\%$ & 15.9 & 17.7 & 29.8 & 27.8 & 8.8 & 2.90 & 1.20 & 11 \\
\hline Listening and & $\mathrm{N}$ & 174 & 152 & 322 & 365 & 187 & 320 & 126 & 7 \\
\hline understanding the content & $\%$ & 14.5 & 12.7 & 26.8 & 30.4 & 15.6 & 3.20 & 1.26 & 7 \\
\hline Cooperation in study group & $\mathrm{n}$ & 200 & 194 & 331 & 341 & 134 & 201 & 124 & 10 \\
\hline work & $\%$ & 16,7 & 16.2 & 27.6 & 28.4 & 11.2 & 3.01 & 1.24 & 10 \\
\hline Idea presentation to & $\mathrm{n}$ & 119 & 191 & 379 & 297 & 214 & 325 & 120 & 4 \\
\hline teachers and classmates & $\%$ & 9.9 & 15.9 & 31.6 & 24.8 & 17.8 & 3.25 & 1.20 & 4 \\
\hline Application of accumulated & $\mathrm{n}$ & 125 & 184 & 274 & 345 & 272 & 230 & 127 & 1 \\
\hline knowledge into reality & $\%$ & 10.4 & 15.3 & 22.8 & 28.8 & 22.7 & 3.38 & 1.27 & 1 \\
\hline Total & & & & & & & 3.18 & 0.98 & \\
\hline
\end{tabular}


Among the 12 items regarding to students' academic advising, the five indicators with the average points ranging from the highest to the lowest are as below: Application of accumulated knowledge into reality (3.38), Appropriate study method for study (3.37), Logical time management for study (3.28), Idea presentation to teachers and classmates (3.25), Compulsory study content identification (3.23). The five indicators with the lowest average points are as below: Note-taking of study content (2.94), Observation during the study (2.96), Cooperation in study group work (3.01), Information management in the study (3.11), Search for the further study material (3.18).

Table 4 shows the correlations between the current existing obstacle and Vietnamese high school students' need for academic advising. Pearson correlation coefficients demonstrated significantly strong positive correlations $(p>0.05)$ between the current existing obstacle and Vietnamese high school students' need for academic advising $(r=0.638, p=0.001)$ (Krehbiel, 2004).

Table 4: Correlations among the study variables

\begin{tabular}{|l|r|r|}
\hline & \multicolumn{1}{|c|}{ Study obstacles } & \multicolumn{1}{c|}{$\begin{array}{c}\text { Need of academic } \\
\text { advising }\end{array}$} \\
\hline Study obstacles & 1 & $0,638^{* *}$ \\
\hline Need of academic advising & $0,638^{* *}$ & 1 \\
\hline$* *$. Correlation is significant at the 0.01 level (2-tailed). \\
\hline
\end{tabular}

\section{Discussion}

This research examined the correlations between the current existing obstacle and Vietnamese high school students' need for academic advising. The main findings indicate that there was a positive and close relationship between students' study obstacle and the need for academic advising. The more obstacles emerge during the study period, the higher the need for academic advising is, especially obstacles listing as Application accumulated knowledge into reality, Appropriate study method identification, Logical study time management. This is a crucial conclusion for further upcoming researches regarding academic advising campaign for Vietnamese high school students that need to be conducted as soon as possible with efficiency. This activity can satisfy students' practical need in order to motivate their spirit as well as to comfort their study facilities in becoming better students as expected. Furthermore, if these students' need is not satisfied as soon as possible, more stress and higher study pressures emerge, leading to more potentially dangerous and unpredictable reactions. This research also found that high school students face the following study obstacles and need of academic advising: Study target/motivation identification, Compulsory study content identification, Appropriate study method identification, Logical time management, Search of further study materials, Information management in study, Note-taking of study content, Observation in study, Listening and understanding study content, Cooperation with classmates in group work, Idea presentation to teachers and classmates, and Application accumulated knowledge into reality. 
To be more specific, the results support the study made by Adeusi (2017), who concluded that it is important for schools to provide adequate and effective counseling service and personnel to works together with the school administrators and teachers to assist students to cope well with the possible challenges they could face in their new environment and to also motivate the students towards achieving excellence. The fact that academic advising is one of the basic ways for the students to logical time management is also supported by Mayberry (2005) found that the counselor's role is to facilitate students' development of time management skills and solid work habits so students can successfully complete homework assignments. Our results further support a prior study made by Dundee (1998), that the school counselor should assume the role of a leader in the school to help teachers and administrators increase student achievement on a regular basis. The developmental academic advising approach is one of the dominant strategies that is designed to promote students' success in higher education. This approach not only enhances the quality of training for students but also reduces students' drop out, increases students' retention and promotes students' motivation. By employing this approach of academic advising, it is hoped that the student will experience the true sense and meaningful eco-system of education.

This study has several limitations. The main limitation arises from the sampling process used. The sample was drawn from only one city of Can Tho, Vietnam. The random selection of participants alleviates this concern to a significant degree but does not completely remedy that shortcoming. The second limitation is related to the sample and the self-reported measurements. This might bias the findings as well, and was cross-sectional research, which does not allow. Future studies should address these limitations by using a longitudinal design with data collected from high school and including more comparison communities.

\section{Conclusion}

High school students are facing many study obstacles so they do require the need of academic advising related to the above obstacles. There was a positive and close relation between study obstacles and the need for academic advising. The more obstacles emerge during the study, the higher the need for academic advising regarding these obstacles becomes. Therefore, counseling activity concerning to study obstacles must be enhanced in order to assist students in overcoming and solving any obstacles arising during their study period as well as organizing their study progress in an appropriate and efficient way.

To the best of the author' knowledge, this is the first research to examine the relationships between the current existing obstacle and Vietnamese high school students' need for academic advising. In addition to the very limited research in this aspect in Vietnam, the results of this research are necessary for Vietnamese school counselors to have a better understanding of their job.

\section{Conflict of Interest}

The authors declared no conflict of interests. 


\section{References}

Adeusi, S. O. (2017). Influence of Guidance and Counseling on Students Motivation and School Adjustment among Covenant University Students, Ogun State. Covenant International Journal of Psychology, 1(2), 11-21.

http:/ / eprints.covenantuniversity.edu.ng/id/eprint/9070

An, G. (2015). In the Mekong Delta poorest homes, education takes a back seat, Thanh Niên News. Retrieved from http://www.thanhniennews.com/educationyouth/in-the-mekong-delta-poorest-homes-education-takes-a-back-seat54242.html

Branham, S. C. (2009). High school students' and counselors' perceptions of counselors' signaling affecting student preparation for college. (Doctoral dissertation), Teachers College, Columbia University, New York, United States. Retrieved from https:/ / search.proquest.com/openview/136327b032fd8863b41937ef927d81fd/1? pq-origsite $=$ gscholar\&cbl $=18750 \&$ diss $=y$

Croasmun, J. T., \& Ostrom, L. (2011). Using Likert-Type Scales in the Social Sciences. Journal of Adult Education, 19-22. https:/ / files.eric.ed.gov/fulltext/EJ961998.pdf

Dellana, S. A., \& Snyder, D. (2004). Student future outlook and counseling quality in a rural minority high school. The High School Journal, 88(1), 27-41. https://www.jstor.org/stable/40364275

Dillman, D. A. (2000). Mail and Internet surveys: The tailored design method. New York: John Wiley \& Sons.

Duc, V. (2013). Một tỉnh gần 5.000 học sinh bỏ học [A province of nearly 5,000 students dropped out], Tuổi Trẻ. Retrieved from https://tuoitre.vn/mot-tinh-gan-5000hoc-sinh-bo-hoc-585493.htm

Dundee, D. (1998). How leaders lead: A new look at leadership behavior with implications for identification and development. AASA Professor, 21(3/4), 4-14.

Flitton, B., \& Buckroyd, J. (2005). Counselling children and young people who attend a school for children with complex needs: A case study. Counselling and

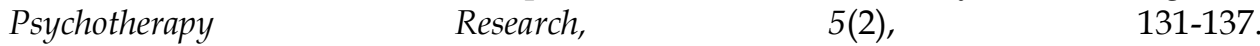
https:/ / doi.org/10.1080/17441690500258701

Gerrity, D., \& DeLucia-Waack, J. (2007). Review of research on group work in schools. The Journal for Specialists in Group Work, 32, 97-106.

Jaafar, M. H., Arifin, K., Aiyub, K., Razman, M. R., \& Kamaruddin, M. A. (2017). Human Element as the Contributing Factor Towards Construction Accidents from the Perspective of Malaysian Residential Construction Industry. Paper presented at the International Conference on Applied Human Factors and Ergonomics. https:/ /link.springer.com/chapter/10.1007/978-3-319-60525-8_31

Krehbiel, T. C. (2004). Correlation coefficient rule of thumb. Decision Sciences Journal of Innovative Education, 2(1), 97-100. https://doi.org/10.1111/j.00117315.2004.00025.x

Lapan, R. T., Gysbers, N. C., \& Petroski, G. F. (2001). Helping seventh graders be safe and successful: A statewide study of the impact of comprehensive guidance and counseling programs. Journal of Counseling \& Development, 79(3), 320-330. https://doi.org/10.1002/j.1556-6676.2001.tb01977.x

Lapan, R. T., Gysbers, N. C., \& Sun, Y. (1997). The impact of more fully implemented guidance programs on the school experiences of high school students: A statewide evaluation study. Journal of Counseling $\mathcal{E}$ Development, 75(4), 292-302. https://doi.org/10.1002/j.1556-6676.1997.tb02344.x 
Legum, H. L., \& Hoare, C. H. (2004). Impact of a career intervention on at-risk middle school students' career maturity levels, academic achievement, and self-esteem. Professional School Counseling, 8(2), 148-155. https://eric.ed.gov/?id=EJ708717

Mayberry, M. (2005). The school counselor's role in easing students' transition from elementary to middle school Vistas : compelling perspectives on counseling (pp. 8385). Alexandria, VA: American Counseling Association. https://www.counseling.org/knowledge-center/vistas/by-subject2/vistaschildren/docs/default-source/vistas/vistas_2005_vistas05-art17

Nguyen, T. V., Hamdan, S., Ros, I. R., Tee, T. C., Noriadah, A. K., \& Norashuha, T. (2013). Developmental academic advising to promote students' success. Paper presented at the International Conference on Vietnamese Studies, Hanoi. https://dulieu.itrithuc.vn/ dataset/a2fa8090-05ff-4226-bfbb25aca39b085a/resource/40dd16a6-0bca-48e6-82e5411c226ccf3f/download/ky_05639.pdf

Pham, A. (2016). TP.HCM có hơn 5.000 học sinh bỏ học [Ho Chi Minh city more than 5000 high school students were dropped out], Ho Chi Minh City Newspaper of Laws. Retrieved from https://plo.vn/xa-hoi/giao-duc/tphcm-co-hon-5000-hocsinh-bo-hoc-646021.html

Phan, C., \& Khanh, A. (2012). Hơn 1.500 học sinh Hà Nội bỏ học [Hanoi capital more than 1,500 high school students were dropped out], Nguòi Đua Tin. Retrieved from https://www.nguoiduatin.vn/hon-1500-hoc-sinh-ha-noi-bo-hoca16305.html

Sculli, N. (2011). Assessing the counseling needs of high school students: The role of needs assessments in comprehensive school counseling programs (CSCPs) and the ASCA national model. (Master's thesis), The State University of New York, New York, United States. Retrieved from https://digitalcommons.brockport.edu/edc_theses/120/

Sink, C. A., Akos, P., Turnbull, R. J., \& Mvududu, N. (2008). An investigation of comprehensive school counseling programs and academic achievement in Washington state middle schools. Professional School Counseling, 12(1), 43-53. https://doi.org/10.1177/2156759x0801200105

Sink, C. A., \& Stroh, H. R. (2003). Raising achievement test scores of early elementary school students through comprehensive school counseling programs. Professional School Counseling, 6(5), 350-364. https://www.jstor.org/stable/pdf/42732452.pdf

Thanh Nien. (2011). School enrolment, dropout rates alarm educationists, Thanh Niên News. Retrieved from http://www.thanhniennews.com/educationyouth/school-enrolment-dropout-rates-alarm-educationists-19458.html 